\title{
The action of rennin on casein
}

The disruption of the $\kappa$-casein complex*

\author{
By R. BEEBY \\ Division of Dairy Research, C.S.I.R.O., Melbourne, Australia \\ AND Hs. NITSCHMANN \\ Institute of Organic Chemistry, University of Berne, Switzerland
}

(Received 23 July 1962)

SUmmary. Approximately $30 \%$ of the nitrogen of $\kappa$-casein was soluble at pH $4 \cdot 7$ after the protein had been treated with rennin at $\mathrm{pH} 7$ while approximately $10 \%$ was soluble in $12 \%$ trichloroacetic acid (TCA). The material soluble in $12 \%$ TCA appeared at a slower rate initially than did the nitrogen soluble at $\mathrm{pH} 4 \cdot 7$ but as the reaction proceeded it was released more rapidly.

Treating $\kappa$-casein with urea, or repeated precipitation of the protein at $\mathrm{pH} 4 \cdot 7$, caused the formation of material insoluble at $\mathrm{pH} 7$, apparently para- $\kappa$-casein. Both treatments appeared to free the same soluble fraction as does rennin acting in low concentration or for a short time.

Low concentrations of rennin $(0.07 \mu \mathrm{g} / \mathrm{ml})$ released only part of the available soluble nitrogen from $2 \%$ solutions of whole casein at $\mathrm{pH} 7$. Heating the reaction mixture appeared to restore the casein complex, the restoration being less complete the longer the reaction had proceeded.

It is suggested that $\kappa$-casein is not a single protein but a complex, and that the action of rennin is first to open the secondary bonds responsible for the stability of this complex.

Although rennin has been shown to possess a proteolytic activity comparable to that of trypsin and a specificity similar to that of pepsin (Fish, 1957), proteolytic cleavage of casein has not been demonstrated with any degree of certainty during its conversion into the calcium-sensitive form (para-casein) by the enzyme.

Alais, Mocquot, Nitschmann \& Zahler (1953) reported the rapid release of peptide material, amounting to some $5 \%$ of the casein nitrogen, from whole casein when it was transformed into para-casein by rennin at $\mathrm{pH} 6 \cdot 8$. The reaction was distinct from the slower general proteolytic degradation of the casein at this $\mathrm{pH}$, and was referred to as the primary action of the enzyme. The liberated material stemmed from

* This work, which was commenced in Berne, Switzerland, and continued in Melbourne, Australia, was reported in brief at a Food Science Conference held in September 1961 at the Division of Food Preservation, C.S.I.R.O., North Ryde, Sydney, Australia. This paper may be considered no. XV of the series: 'Das Lab und seine Wirkung auf das Casein der Milch'. No. XIV is Nitschmann, Hs. \& Beeby, R. (1960). Chimia, 14, 318. 
the $\alpha$-casein fraction, and later Wissmann \& Nitschmann (1957) reported the appearance of phenylalanine as a new $N$-terminal residue in $\alpha$-casein following treatment with rennin. This led to the conclusion that the primary action of the enzyme was one of specific limited hydrolysis.

A further advance was made when Waugh \& von Hippel (1956) isolated $\kappa$-casein, a component of the $\alpha$-casein complex. The peptide material freed during the primary attack by rennin on casein was shown to originate from this fraction (Waugh \& von Hippel, 1956; Garnier, 1957; Wake, 1959). Wake (1959) found no difference between the $N$-terminal residues of $\kappa$-casein before and after treatment with rennin and concluded that no peptide bonds had been split. Howerer, the quantity of $\alpha$-amino groups found was in the range $0 \cdot 12-0 \cdot 16 /$ mole per $10^{5} \mathrm{~g}$ of protein which is so low as to make such a conclusion uncertain.

In the present study evidence is presented that the primary action of rennin on casein is more complex than has been assumed so far and that the first step consists in liberating a component from the $\kappa$-casein fraction by the rupture of secondary bonds only.

\section{EXPERIMENTAL}

\section{Materials}

All reagents were of analytical grade. The rennin was either crystalline or in a form in which crystallization could be induced by seeding. Stock rennin solutions were stored at $5^{\circ} \mathrm{C}$ with thymol.

Whole casein was precipitated from raw skim-milk by slowly adjusting the $\mathrm{pH}$ to 4.6 with $\mathrm{N}-\mathrm{HCl}$. The precipitated protein was washed with distilled water and then extracted at $\mathrm{pH} 4 \cdot 0$ (acetic acid) for $5 \mathrm{~h}$ to remove proteolytic enzymes as described by McMeekin, Hipp \& Groves (1959). The precipitate was dissolved by the addition of $\mathrm{N}-\mathrm{NaOH}$, taking care that the $\mathrm{pH}$ of the solution did not rise above $7 \cdot 5$, and the protein precipitated again with $\mathrm{N}-\mathrm{HCl}$. After four precipitations the casein was dried with absolute alcohol followed by ether, and ground. Casein solutions were prepared by mixing the dried protein with water and adding $\mathrm{N}-\mathrm{NaOH}$ dropwise until solution was complete.

$\kappa$-Casein was prepared according to the procedure of McKenzie \& Wake (1961) except that the urea step was omitted and the precipitated $\kappa$-casein dissolved at $\mathrm{pH} 7-7.5$ by the addition of $0 \cdot 1 \mathrm{~N}-\mathrm{NaOH}$. After precipitation at $\mathrm{pH} 4 \cdot 7$ the protein was dissolved again at $\mathrm{pH} 7-7 \cdot 5$ and the solution freeze-dried. The yield was approximately $0.9 \mathrm{~g} / \mathrm{l}$ of skim-milk.

Another method based on the procedure of Waugh \& von Hippel (1956) and yielding $3-4 \mathrm{~g}$ of $\kappa$-casein per litre of skim-milk was developed in which the $\alpha-\kappa$ complex was split in a dilute state to minimize interactions and consequent loss of $\kappa$-casein by co-precipitation with $\alpha$ - and $\beta$-casein. Whole casein was precipitated and protease removed as described above. After a second precipitation the protein was dissolved at $\mathrm{pH} 7$ by the addition of $\mathrm{N}-\mathrm{NaOH}$, the concentration of protein adjusted to $2-3 \%$, and the solution cooled to $2{ }^{\circ} \mathrm{C}$. Calcium chloride $(80 \%, \mathrm{w} / \mathrm{v})$ was added slowly to give a final calcium concentration of $0.27 \mathrm{M}$, the $\mathrm{pH}$ being maintained at 7 by the addition of $0.1 \mathrm{~N}-\mathrm{NaOH}$. The mixture was held at $2{ }^{\circ} \mathrm{C}$ for $30 \mathrm{~min}$ after which it was warmed to $37^{\circ} \mathrm{C}$. The turbid supernatant was decanted from the precipitate 
that had formed, centrifuged for $30 \mathrm{~min}$ at $20000 \mathrm{rev} / \mathrm{min}$ in a Spinco model $\mathrm{L}$ ultracentrifuge (rotor 21), and dialysed overnight against running water. The dialysed solution was reduced to $10 \%$ of its original volume in a stainless steel evaporator at $30^{\circ} \mathrm{C}$ and treated again with calcium as described. The turbid solution was then centrifuged for $45 \mathrm{~min}$ at $20000 \mathrm{rev} / \mathrm{min}$. The clear supernatant was dialysed at $2{ }^{\circ} \mathrm{C}$ against 20 volumes of $0 \cdot 1 \mathrm{M}-\mathrm{NaCl}$ for $24 \mathrm{~h}$. The dialysis was repeated twice and the dialysed solution freeze-dried.

Thymol was added to all casein solutions during the preparation of whole casein and $\kappa$-casein.

\section{METHODS}

Casein solutions were treated with rennin at $25^{\circ} \mathrm{C}$.

Total nitrogen was determined by a micro-Kjeldahl procedure.

Portions were taken during the reaction with rennin and the casein precipitated by the addition of either a one-tenth volume of acetic acid-sodium acetate buffer (M with respect to each) or an equal volume of $24 \%$ (w/v) TCA. The soluble nitrogen released by rennin was estimated in the filtrates by a modification of the method described by Brown, Duda, Korkes \& Handler (1957). A sample of filtrate $(0 \cdot 1$ $0.5 \mathrm{ml}$ ) containing up to $5 \mu \mathrm{g} \mathrm{N}$ was digested in a test tube with $1 \mathrm{ml}$ of acid reagent ( $10 \mathrm{ml}$ of concentrated $\mathrm{H}_{2} \mathrm{SO}_{4}+15 \mathrm{~g} \mathrm{~K}_{2} \mathrm{SO}_{4}$ made up to $100 \mathrm{ml}$ with distilled water). The digestion was continued for $1 \frac{1}{4} \mathbf{h}$ after the water had evaporated. Five $\mathrm{ml}$ of distilled water was added to the cooled sample. When solution of the hydrated sulphate was complete $1 \mathrm{ml}$ of phenolate reagent and $2 \mathrm{ml}$ of saturated $\mathrm{Na}_{3} \mathrm{PO}_{4}$ were added and the contents of the tube mixed. One $\mathrm{ml}$ of $0.02 \%$ sodium nitroprusside was then added and, after mixing, $1 \mathrm{ml}$ of $0.1 \mathrm{~m}$-sodium hypochlorite. The phenolate reagent contained $2 \cdot 5 \mathrm{~g}$ of phenol $+16 \mathrm{~g}$ of $\mathrm{NaOH}$ per $100 \mathrm{ml}$ and was adjusted so that $1 \mathrm{ml}$ just neutralized (to methyl red) $1 \mathrm{ml}$ of acid reagent. The colour was developed by heating in a bath at $100^{\circ} \mathrm{C}$ for 5 min and when cool the optical density was measured at $625 \mathrm{~m} \mu$. Determinations were made in triplicate.

For paper electrophoresis an EEL unit was used at $4{ }^{\circ} \mathrm{C}$. The strips were dried at $103^{\circ} \mathrm{C}$ for $20 \mathrm{~min}$ and the protein bands stained by immersing for $20 \mathrm{~min}$ in $0.1 \%$ bromphenol blue in ethanol containing $2 \% \mathrm{HgCl}_{2}$.

\section{The release of soluble nitrogen from $\kappa$-casein by rennin}

Rennin $(0 \cdot 14 \mu \mathrm{g} / \mathrm{ml})$ was added to a $0.5 \%$ solution of $\kappa$-casein ( $\mathrm{pH} 7$ ) and the release of nitrogen soluble at $\mathrm{pH} 4.7$ and in $12 \%$ TCA determined. As Fig. 1 shows, the release of nitrogen soluble at $\mathrm{pH} 4.7$ was initially considerably faster than the release of nitrogen soluble in $12 \%$ TCA. As the reaction proceeded the nitrogen soluble in $12 \%$ TCA accounted for a greater proportion of the nitrogen soluble at pH $4 \cdot 7$, the proportions being approximately 20 and $33 \%$ respectively in the early stages and the end of the reaction.

The release of soluble nitrogen from $\kappa$-casein was accompanied by aggregation and eventually by precipitation of the para- $\kappa$-casein. These aggregates were difficult to disperse and persisted even at $\mathrm{pH} 10-11$.

The soluble material released during the early stages of rennin action was isolated as follows. Rennin $(0 \cdot 14 \mu \mathrm{g} / \mathrm{ml})$ was added to a $1 \% \kappa$-casein solution $(\mathrm{pH} 7)$ and 
after $5 \mathrm{~min}$ the enzyme was inactivated by heating the mixture. When cool the solution was adjusted to $\mathrm{pH} 4.7$ by the addition of $0.1 \mathrm{~N}-\mathrm{HCl}$, the precipitate removed by centrifugation $(60000 \mathrm{~g})$ and the supernatant freeze-dried after adjusting to $\mathrm{pH} 7$ with $0.1 \mathrm{~N}-\mathrm{NaOH}$. Salt was removed by dissolving the freeze-dried material in distilled water and passing through a column of G 25 Sephadex (Porath \& Flodin, 1959). The desalted solution was freeze-dried.

Para- $\kappa$-casein was prepared by allowing the reaction with rennin to proceed for $40 \mathrm{~min}$. The protein was then precipitated at $\mathrm{pH} 4 \cdot 7$, filtered and washed. The precipitated para- $\kappa$-casein was titrated to $\mathrm{pH} 11$ with $\mathrm{N}-\mathrm{NaOH}$, to break up the large aggregates, the $\mathrm{pH}$ reduced to 7 with $\mathrm{N}-\mathrm{HCl}$ and the suspension freeze-dried.

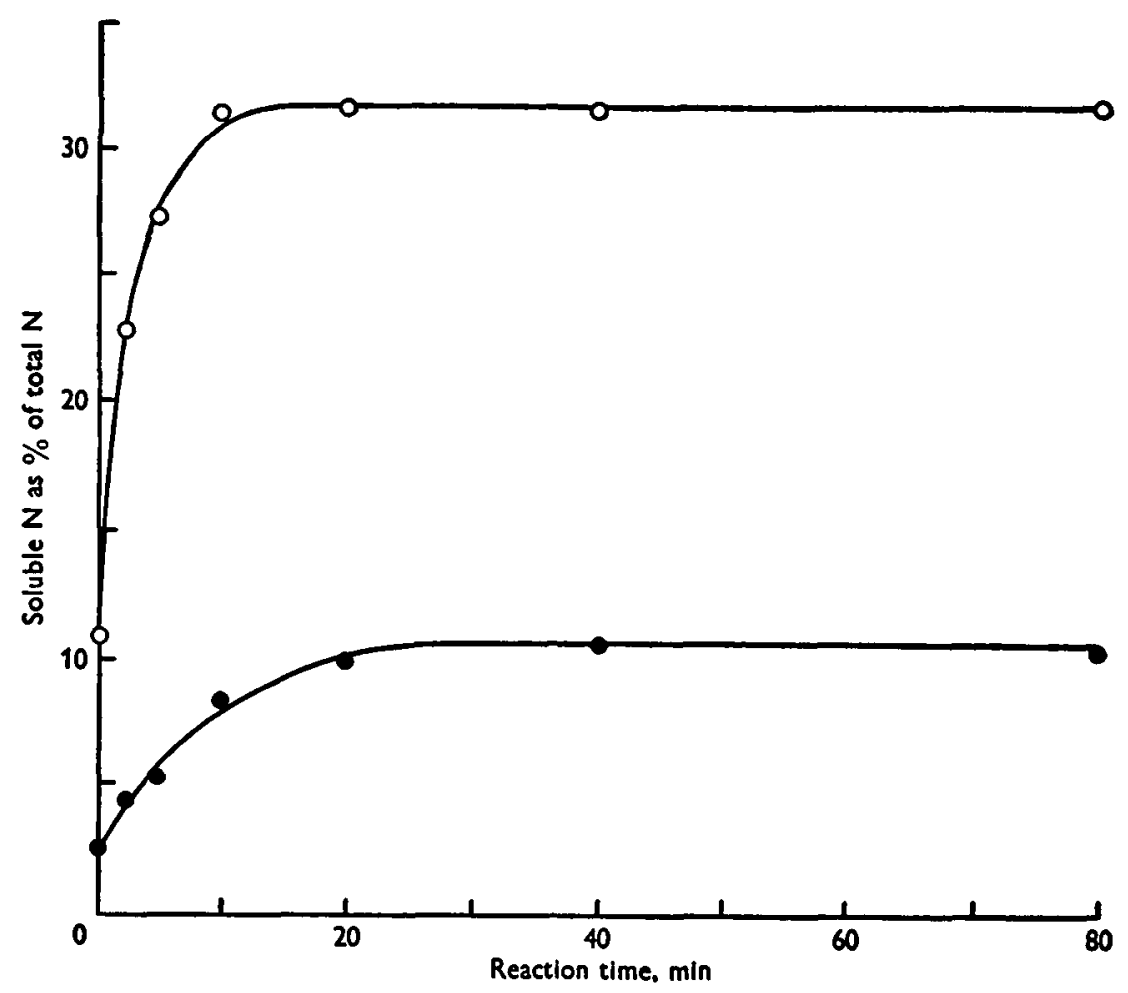

Fig. 1. The rate of release of soluble nitrogen in a $\alpha$-casein solution $(0.5 \%)$ containing rennin $(0.14 \mu \mathrm{g} / \mathrm{ml})$ at $25^{\circ} \mathrm{C}$ and $\mathrm{pH} 7$. $O$, Nitrogen soluble at $\mathrm{pH} 4 \cdot 7 ; \bullet$, nitrogen soluble in $12 \%$ TCA.

\section{The effect of urea on $\kappa$-casein}

In the method of McKenzie \& Wake (1961) for the preparation of $\kappa$-casein the protein is precipitated from $50 \%$ ethanol by ammonium acetate. The precipitate is dissolved in $6 \mathrm{M}$-urea and the urea removed by dialysis against $0.005 \mathrm{M}-\mathrm{NaCl}$. When $\kappa$-casein was prepared according to this method a precipitate began to form $10 \mathrm{~min}$ after dialysis had commenced. At the completion of dialysis the precipitated protein was, like para- $\kappa$-casein, insoluble at $\mathrm{pH} 7$ and only partially dispersed at $\mathrm{pH} 10-11$. Rennin released no soluble nitrogen from this material at $\mathrm{pH} 7$.

The cause of precipitation was traced to impure ammonium acetate which was found to contain acetic acid. This lowered the $\mathrm{pH}$ to approximately $5 \cdot 0$. When 
$\kappa$-casein was dissolved in $6 \mathrm{M}$-urea and the urea removed as above precipitation occurred after $24 \mathrm{~h}$. This was apparently due to absorption of carbon dioxide by the solution, which caused the $\mathrm{pH}$ to drop to 5 . This precipitate, however, dissolved readily at $\mathrm{pH}$ 7. The addition of rennin to the solution caused the release of soluble nitrogen and the formation of insoluble para- $\kappa$-casein. Thus the material with properties similar to para- $\kappa$-casein formed only when precipitation occurred before the bulk of the urea had had time to dialyse away.

The effect of urea in breaking down $\kappa$-casein into soluble and insoluble fractions was further studied. Two $\mathrm{g}$ of $\kappa$-casein was dissolved in $100 \mathrm{ml}$ of $6 \mathrm{M}$-urea which contained acetic acid-sodium acetate buffer $(0.01 \mathrm{~m}$ with respect to each). The solution was then dialysed for $24 \mathrm{~h}$ against $10 \mathrm{l}$ of the acetate buffer $(\mathrm{pH} 4 \cdot 7)$ at $2^{\circ} \mathrm{C}$. The dialysis was repeated. The precipitate was collected by filtration, washed with distilled water and dispersed at $\mathrm{pH} 7$. The fraction insoluble at $\mathrm{pH} 7$ was collected by centrifugation, dispersed briefly at $\mathrm{pH} 11$, the $\mathrm{pH}$ reduced again to 7 and the suspension freeze-dried. The filtrate was dialysed for $5 \mathrm{~h}$ against $10 \mathrm{l} \mathrm{of} 0.01 \mathrm{~m}-\mathrm{NaCl}$, centrifuged $30 \mathrm{~min}$ at $60000 \mathrm{~g}$ and freeze-dried. Salt was removed as described by Porath \& Flodin (1959). The yield of the soluble fraction was approximately $0.4 \mathrm{~g}$ or $20 \%$.

\section{The effect of precipitation at $\mathrm{pH} 4 \cdot 7$ on $\kappa$-casein}

Before treatment with rennin approximately $10 \%$ of the total nitrogen of $\kappa$-casein was soluble at $\mathrm{pH} 4 \cdot 7$ (Fig. 1). This soluble material was apparently not $\kappa$-casein because the solution developed no turbidity when treated with rennin at $\mathrm{pH} 7$, while a $\kappa$-casein solution with half the nitrogen content $(4 \mathrm{mg} \mathrm{N} / 100 \mathrm{ml})$ became distinctly turbid under these conditions. Also the dilute $\kappa$-casein solution was turbid at $\mathrm{pH} 4 \cdot 7$ while the other preparation was clear.

Fifty $\mathrm{ml}$ of a $4 \%$ solution of $\kappa$-casein was adjusted to $\mathrm{pH} 4.7$ with $0.1 \mathrm{~N}-\mathrm{HCl}$ and the precipitated protein separated by filtration. The precipitate was dissolved at $\mathrm{pH} 7-7.5$ by the addition of $0.1 \mathrm{~N}-\mathrm{NaOH}$ and again precipitated at $\mathrm{pH} 4.7$. After four precipitations the combined filtrates were centrifuged for $30 \mathrm{~min}$ at $60000 \mathrm{~g}$, adjusted to $\mathrm{pH} 7$ with $0 \cdot 1 \mathrm{~N}-\mathrm{NaOH}$ and freeze-dried. Salt was removed as described by Porath \& Flodin (1959). The yield was approximately $0.3 \mathrm{~g}$ or $15 \%$.

The precipitated $\kappa$-casein contained more material insoluble at $\mathrm{pH}$ 7-7.5 after each precipitation. The final precipitate was dispersed at $\mathrm{pH} 7$ and centrifuged for $30 \mathrm{~min}$ at $60000 \mathrm{~g}$. The sediment was suspended at $\mathrm{pH} 7$ and freeze-dried. The supernatant was freeze-dried, yielding approximately $0.8 \mathrm{~g}$ or approximately $40 \%$ of apparently unchanged $\kappa$-casein (paper electrophoresis).

\section{The soluble and insoluble fractions from $\kappa$-casein}

The insoluble fractions resulting from the treatment of $\kappa$-casein with urea and from repeated precipitation at $\mathrm{pH} 4.7$ were compared with para- $\kappa$-casein by paper electrophoresis on Whatman $3 \mathrm{MM}$ paper in $0.01 \mathrm{M}-\mathrm{KOH}-0.01 \mathrm{M}-\mathrm{KCl}(\mathrm{pH} \mathrm{11} \cdot 7)$. The patterns are shown in Plate 1. The three insoluble fractions had similar mobilities which were less than that of $\kappa$-casein, suggesting strongly that para- $\kappa$-casein had been formed by the treatment with urea and by precipitation at $\mathrm{pH} 4 \cdot 7$.

The soluble fractions obtained from $\kappa$-casein by treatment with rennin, with urea, 
and by precipitation were compared by paper electrophoresis on Whatman $3 \mathrm{MM}$ paper in veronal buffer (ionic strength $0.02, \mathrm{pH} 8 \cdot 6$ ). The three preparations gave similar patterns (Plate 2). The bulk of the material moved towards the cathode under these conditions in contrast to $\kappa$-casein which moved towards the anode.

The soluble fractions were analysed for total nitrogen (Kjeldahl), total phosphorus (Fiske \& Subbarow, 1925), arginine (Macpherson, 1946) and sialic acid expressed as $N$-acetyl neuraminic acid (Warren, 1959). The results are given in Table 1.

Table 1. Nitrogen, phosphorus, arginine and sialic acid contents of the soluble components obtained from $\kappa$-casein by treatment with rennin, urea or precipitation at $\mathrm{pH} 4 \cdot 7$

$\begin{array}{lcccc}\begin{array}{c}\text { Fraction freed from } \\ \kappa \text {-casein by }\end{array} & \% \mathrm{~N} & \% \mathrm{P} & \begin{array}{c}\% \\ \text { arginine }\end{array} & \begin{array}{c}\% \text { sialic } \\ \text { acid }\end{array} \\ \text { (1) Rennin } & 13.6 & 0.8 & 2.9 & 3.8 \\ \text { (2) Urea } & 14.1 & 0.8 & 2 \cdot 4 & 3 \cdot 1 \\ \text { (3) Pptn. at pH 4.7 } & 13.4 & 0.6 & 2.3 & 2 \cdot 1\end{array}$

The soluble sample prepared by precipitation of $\kappa$-casein at $\mathrm{pH} 4.7$ contained less sialic acid and phosphorus than the other two samples although the ratio of sialic acid to phosphorus was similar for each. This suggests that this sample may have contained other material deficient in both sialic acid and phosphorus. However, the rest of the data and their electrophoretic properties (Plate 2) indicated that the three samples were at least very similar. This fact, together with the formation of material closely resembling para- $\kappa$-casein during the precipitation of $\kappa$-casein or its treatment with urea, suggested strongly that the same material was split from $\kappa$-casein by these treatments as was released by the action of rennin. If the enzyme were to act by disrupting secondary forces rather than breaking covalent bonds then inactivating the enzyme might be expected to reverse the process and cause a decrease in the soluble nitrogen.

\section{The effect of heating a rennin-casein mixture on the release of soluble nitrogen}

Because aggregation accompanied the release of soluble nitrogen from $\boldsymbol{\kappa}$-casein and the aggregates were difficult to disperse, whole casein was used to check the possibility of reversal of the release of soluble nitrogen. The slower appearance of nitrogen soluble in $12 \%$ TCA compared with that soluble at $\mathrm{pH} 4.7$ indicated the likelihood of a breakdown of the released material after it had been freed. To minimize this effect a low concentration of rennin was used.

A $2 \%$ whole casein solution was treated with rennin $(0.07 \mu \mathrm{g} / \mathrm{ml})$ at $\mathrm{pH} 7$ and duplicate portions taken at intervals to determine the rate of release of nitrogen soluble at $\mathrm{pH} 4 \cdot 7$. One series was heated for $4-5 \mathrm{~min}$ at $80^{\circ} \mathrm{C}$ before precipitating the casein and another series not heated. The results (Fig. 2) show that this concentration of rennin rapidly released approximately $2 \%$ of the casein nitrogen. Heating prior to precipitation caused a decrease in the nitrogen content of the filtrates. The difference between heated and non-heated samples became less as the reaction proceeded.

When a higher concentration of rennin $(1 \cdot 14 \mu \mathrm{g} / \mathrm{ml})$ was used, the soluble nitrogen in filtrates from heated and non-heated portions was $2 \cdot 6$ and $3.4 \%$ respectively after $5 \mathrm{~min}$ reaction and 4.9 and $5.1 \%$ respectively after $30 \mathrm{~min}$. This figure of $5 \%$ 


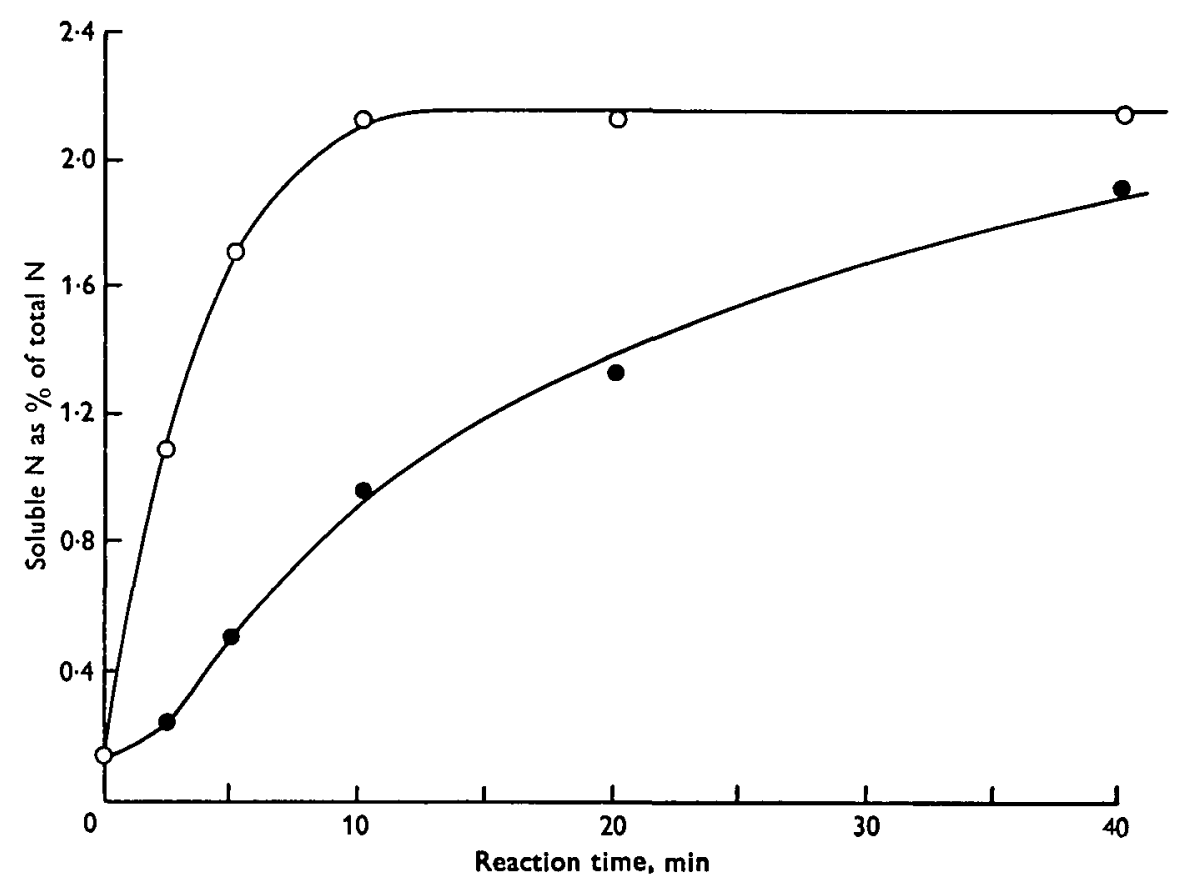

Fig. 2. The effect of heating to $80^{\circ} \mathrm{C}$ for $5 \mathrm{~min}$ on the nitrogen soluble at pH 4.7 in a $2 \%$ solution of whole casein containing $0.07 \mu \mathrm{g}$ of rennin per $\mathrm{ml}\left(25^{\circ} \mathrm{C}\right.$ and $\left.\mathrm{pH} 7\right) . \quad$, Non-heated samples;, heated samples.

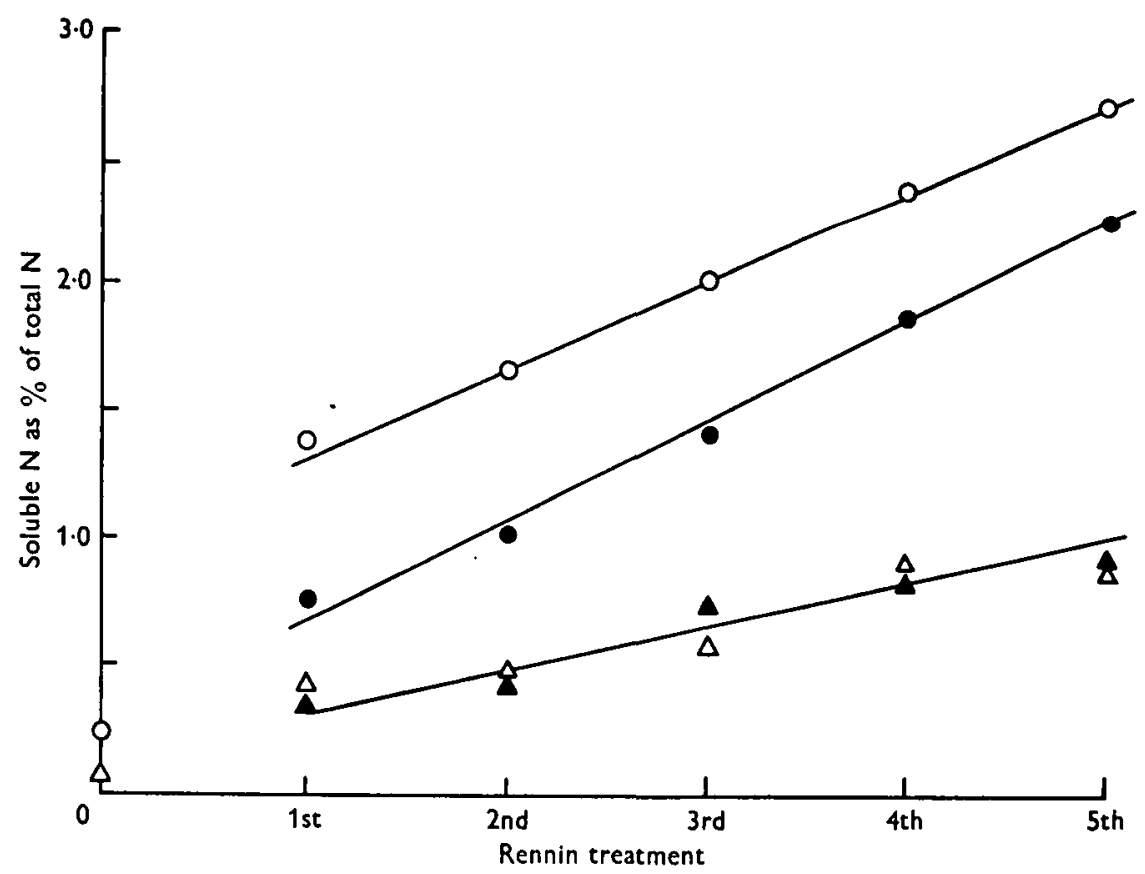

Fig. 3. The release of soluble nitrogen from whole casein by successive treatments of $10 \mathrm{~min}$ duration with rennin $(0.07 \mu \mathrm{g} / \mathrm{ml})$ at $25^{\circ} \mathrm{C}$ and $\mathrm{pH} 7.0$, Nitrogen soluble at $\mathrm{pH} 4.7$ before heating; $\odot$, nitrogen soluble at $\mathrm{pH} 4.7$ after heating; $\triangle$, nitrogen soluble in $12 \%$ TCA before heating; $\Delta$, nitrogen soluble in $12 \%$ TCA after heating. 
agrees with that found by Alais et al. (1953) for the amount of soluble nitrogen that could be released from whole casein by rennin.

The lower content of soluble nitrogen in the heated samples was consistent with the expected recombination of the freed fraction with the casein. If this were so then it should be possible to release it again by adding more rennin.

To test this possibility a $2 \%$ whole casein solution ( $\mathrm{pH} 7$ ) was treated with rennin $(0.07 \mu \mathrm{g} / \mathrm{ml})$, and after $10 \mathrm{~min}$ the enzyme was inactivated by heating as described. The mixture was cooled, fresh rennin added $(0.07 \mu \mathrm{g} / \mathrm{ml})$ and the reaction stopped again after $10 \mathrm{~min}$. In this way the casein solution was given five separate treatments. with rennin. Portions were removed before and after inactivation of the enzyme each time and the soluble nitrogen determined. In one series the casein was precipitated at $\mathrm{pH} 4.7$ and in another with $12 \% \mathrm{TCA}$. The results are given in Fig. 3. The amounts. of nitrogen soluble in $12 \%$ TCA released by each addition of enzyme were approximately equal and were little affected by inactivation of the rennin. In contrast to. this the nitrogen soluble at $\mathrm{pH}$ 4.7 was always higher before heating than after, although the difference became less with increasing number of enzyme treatments. Extrapolation indicated that the two would coincide at $5 \%$ of the casein nitrogen, which is the total amount of soluble nitrogen available for release (Alais et al. 1953 . and present paper).

The amount of nitrogen soluble at $\mathrm{pH} 4 \cdot 7$ found after the fifth treatment was. $2.3 \%$ of the casein nitrogen. However, the sum of the amounts freed by the separate rennin treatments, which represents the total amount that had actually been released by the enzyme during the course of the experiment, was $4.7 \%$ of the casein nitrogen. In a separate experiment in which the number of enzyme treatments was. nine, the total nitrogen released was $8 \%$ while the nitrogen content of the filtrate after the ninth addition of rennin was $4 \cdot 3 \%$ and fell to $3 \cdot 9 \%$ on heating.

\section{DISCUSSION}

The experiments in which whole casein was subjected to successive treatments. with rennin show clearly that part of the material released by the enzyme is bound by the casein when the mixture is heated. Since a sufficient number of rennin treatments. appears to set free more soluble nitrogen than is available for release, it is apparent. that the portion that is bound on heating is released again during the subsequent enzyme treatments. This suggests strongly that the original casein complex is reformed under these conditions and, therefore, that covalent bonds are not broken in releasing the soluble material.

The difference between the nitrogen contents of the heated and non-heated samples. represents the amount that recombines. However, as the rennin action proceeds, the nitrogen soluble at $\mathrm{pH} 4 \cdot 7$ loses its ability to re-form the casein complex (Figs. 2, 3), indicating that it is altered by the enzyme. Further evidence that this is so is obtained from the fact that the nitrogen soluble in $12 \%$ TCA forms a constant proportion of the nitrogen soluble at $\mathrm{pH} 4 \cdot 7$ that is found after heating, i.e. the nitrogen that can no longer recombine with the para-casein. Also, the nitrogen which cannot re-form the casein complex appears initially at a slower rate than the total nitrogen released, but later it appears at a faster rate (Fig. 2). 
That portion of the nitrogen released from casein by rennin which is soluble in $12 \%$ TCA was shown by Alais (1956) and Nitschmann, Wissmann \& Henzi (1957) to consist almost exclusively of a single peptide with a molecular weight in the region of 8000 and containing sialic acid and other carbohydrate material. It seems most probable therefore that the glycopeptide is not released directly from the casein but is formed as a result of the degradation of a fraction that rennin first releases from the casein. Since the glycopeptide does not recombine with the para-casein on heating (Fig. 3), it is most likely formed by the rupture of a covalent bond; Garnier, Mocquot \& Brignon (1962) have suggested an ester bond.

The experiments with $\kappa$-casein provide considerable substantiation for the above hypothesis. Precipitation of the protein at $\mathrm{pH} 4.7$ or treatment with urea releases material which contains sialic acid and which is very similar to the material split off by rennin. At the same time insoluble material which markedly resembles para- $\kappa$ casein is formed. This indicates that $\kappa$-casein is not a single protein but a complex stabilized by secondary forces such as hydrogen bonds. The existence of such a complex would explain the electrophoretic heterogeneity observed in $\kappa$-casein preparations under disaggregating conditions (Libbey \& Ashworth, 1961; Neelin, Rose \& Tessier, 1962). In the presence of rennin the glycopeptide appears initially at a slower rate than does the nitrogen soluble at $\mathrm{pH} 4.7$ but later it appears more rapidly (Fig. 1), again indicating that it is formed from material that is first released by the enzyme.

The first specific action of rennin on casein therefore appears to be the rapid disruption of the $\kappa$-casein complex by the opening of the secondary bonds responsible for its stability.

The authors wish to thank Mr G. Loftus Hills, Mr R. D. Hill and Dr N. Snow, Division of Dairy Research, C.S.I.R.O., for helpful discussion during the preparation of the manuscript. Thanks are also due to the Board of Directors, Theodor-Kocher Institute, Berne, for providing facilities for one of us (R. B.) at the Institute.

\section{REFERENCES}

AraIs, C. (1956). Proc. 14th Int. Dairy Congr. 2, 823.

Aluts, C., Mocquot, G., Nitschmann, Hs. \& ZahLer, P. (1953). Helv. chim. acta, 36, 1955.

Brown, R. H., DudA, G. D., Korkes, S. \& BandeEr, P. (1957). Arch. Biochem. Biophys. $66,301$.

Fish, J. C. (1957). Nature, Lond., 180, 345.

Fiske, C. H. \& SubBarow, Y. (1925). J. biol. Chem. 66, 375

Garnier, J. (1957). Proc. Intern. Symposium Enzyme Chem. Tokyo and Kyoto, 2, 524. Cited Chem. Abstr. 53, $17212 a$.

Garnier, J., Mocquot, G. \& Brianon, G. (1962). C.R. Acad. Sci., Paris, 254, 372.

LibBey, L. M. \& Ashworth, U. S. (1961). J. Dairy Sci. 44, 1016.

MAcPHERSon, H. T. (1946). Biochem. J. 40, 470.

MoKenzie, H. A. \& WAKE, R. G. (1961). Biochim. biophys. Acta, 47, 240.

MoMeekin, T. L., HIPP, N. J. \& Groves, M. L. (1959). Arch. Biochem. Biophys. 83, 35.

Neitit, J. M., Rose, D., \& Tessier, H. (1962). J. Dairy Sci. 45, 153.

NitsohmanN, Hs., WissmanN, H. \& Henzi, R. (1957). Chimia, 11, 76.

Porath, J. \& Flodin, P. (1959). Nature, Lond., 183, 1657.

WAKE, R. G. (1959). Aust. J. biol. Sci. 12, 479.

WARREN, L. (1959). J. biol. Chem. 234, 1971.

WAUGH, D. F. \& voN H.PPEL, P. H. (1956). J. Amer. chem. Soc. 78, 4576.

Wissmann, H. \& Nitschmans, Hs. (1957). Helv. chim. acta, 40, 356. 


\section{EXPLANATION OF PLATES}

Plate 1

Paper-electrophoresis patterns of $\kappa$-casein and the insoluble fractions resulting from treatment of the protein with rennin, urea and precipitation at pH 4.7. The samples were run in KOH-KCl buffer at pH $11.7(\mu=0.02)$ for 16 h at $150 \mathrm{~V}$. A, $\kappa$-casein; B, fraction from treatment with rennin; C, fraction from treatment with urea; $\mathrm{D}$, fraction obtained by precipitation at $\mathrm{pH} 4 \cdot \mathbf{7}$.

\section{Piate 2}

Paper-electrophoresis patterns of $\kappa$-casein and the soluble fractions resulting from treatment of the protein with rennin, urea and precipitation at $\mathrm{pH} 4 \cdot \mathbf{7}$. The samples were run in veronal-acetate buffer at pH $8.6(\mu=0.02)$ for $16 \mathrm{~h}$ at $200 \mathrm{~V}$. A, $\kappa$-casein; B, fraction from treatment with urea; C, fraction obtained by precipitation at $\mathrm{pH} 4 \cdot 7 ; \mathrm{D}$, fraction from treatment with rennin. 


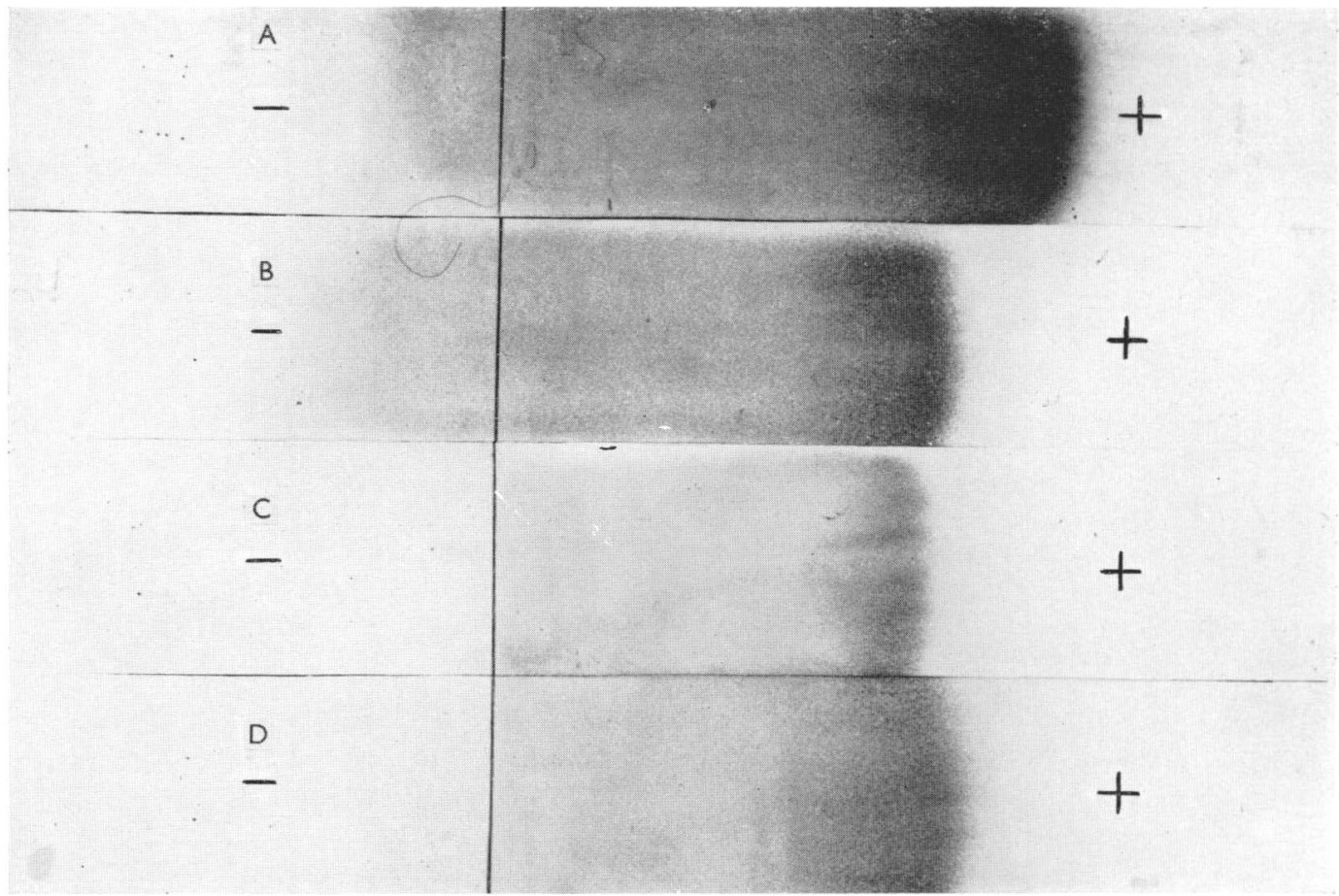




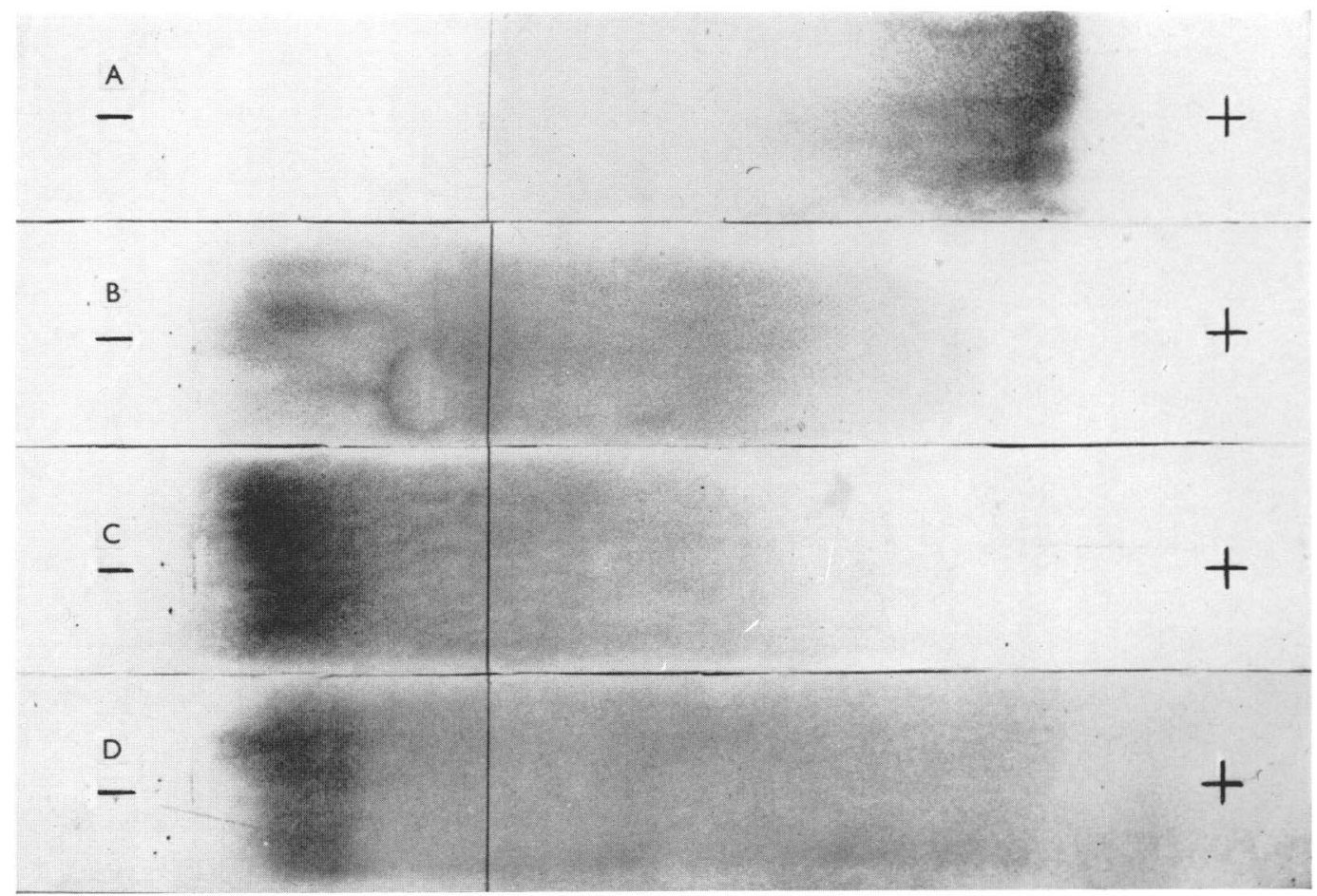

R. BEEBY AND Hs. NITSCHMANN 